TURIZAM

Volume 13

Issue 2, 92-101 (2009)

\title{
Theoretical and Practical Approach of Connecting the Ecotourist Offer of the Special Nature Reserve of Zasavica (Serbia) with the Tourist Offer of the Surrounding Village Settlements
}

\author{
Dragan Dolinaj* 。 \\ Milana Pašić* \\ Vladimir Stojanović* \\ Received: September 2009| Accepted: December 2009
}

\begin{abstract}
Pannonian basin was once covered by vast alluvial plains with patches of marsh, swamp, pan and prairie. With Holocene changes in climate, marshes have withdrawn and in the last couple hundreds of years they were pushed out by developing agricultural areas. The Nature Reserve Zasavica keeps the remains of former marshes and swamps on the territory of Vojvodina. One of the ways for providing necessary financial support for the reserve protection is development of ecotourist activities in the Zasavica region. Its biodiversity and numerous endangered species (Umbra krameri, Nymphaca alba, Numphar luteum, Stratiotes aloides, Acorus calamus, Buteo butes, Haliateetus albicilla, Lutra lutra, Castor fiber...) could be the basis for tourist valorization of the Reserve. It is also necessary to conduct analyses of the impact of tourism on endangered species and confirm sustainability of those activities. The lack of accommodation capacities could be supplemented by the development of the tourist offer of the nearby countryside. This way the village tourism would enrich its offer with visits to the nature reserve. Such tourism activities would contribute towards the development of local communities and the improvement of the standard of living. Since the villages and the reserve are already territorially intertwined, their further tourist cooperation would lead to knowledge transfer and local people would have a better understanding of the protection of the Special Nature Reserve Zasavica.
\end{abstract}

Key words: Zasavica, ekotourism, rural tourism, Vojvodina, Serbia.

* Department of Geography, Tourism and Hotel Management, Faculty of Science, University of Novi Sad, Trg Dositeja Obradovića 3, 21000 Novi Sad, Serbia

- Corresponding author: dragan.dolinaj@dgt.uns.ac.rs 


\section{Introduction}

Zasavica is situated in the furthest north-western part of the Serbia Proper, i.e. in the northwestern part of Mačva (Map 1). Administratively, a large part of it belongs to the Autonomous Province of Vojvodina and the municipality of Sremska Mitrovica, whereas the south-western part belongs to the municipality of Bogatić. The historic development of Zasavica depended on the fact that it is situated between the two big rivers - to the west of the river Drina and to the north and north-east of the river Sava. The Drina, in the geological past, pushed the Sava to the north and formed a vast deposited lowland (Macro-floodplain Mačva-Semberija). Earlier Quartenary movements of the river streams of Drina and Sava across Mačva and Semberija are the results of the climate changes, the processing of the terrain depression in Mačva and the flattening during the lowering of the Srem neogenic blocks, strong accumulation, lowlands of the inconsistent rocks, mild inclines of riverbeds and their tendency to shorten and deepen under the particular circumstances (Marković, 1961). The Mačva lowland, where Zasavica is situated, is mildly, slightly inclined from the south to the north. On the entire territory, there are specific geomorphologic masses. Above all, there are elongated depressions and narrow elongated natural levees. The depressions are much more common form than natural levees. In most of these depressions the water is retained and the swamps are created. The natural levees were created from the river accumulation materials and represent higher and drier land. They are common in the strip between Ravanj and Banovo Polje. The natural levees of the Drina stretch in the direction south-north, and the levees of Sava in the direction west-east. With its meandering stream which is $33.1 \mathrm{~km}$ long (Markoska, 1986), it flows through several settlements of Mačva: Crna Bara, Banovo Polje, Ravnje, Radenković, Zasavica, Noćaj, Salaš

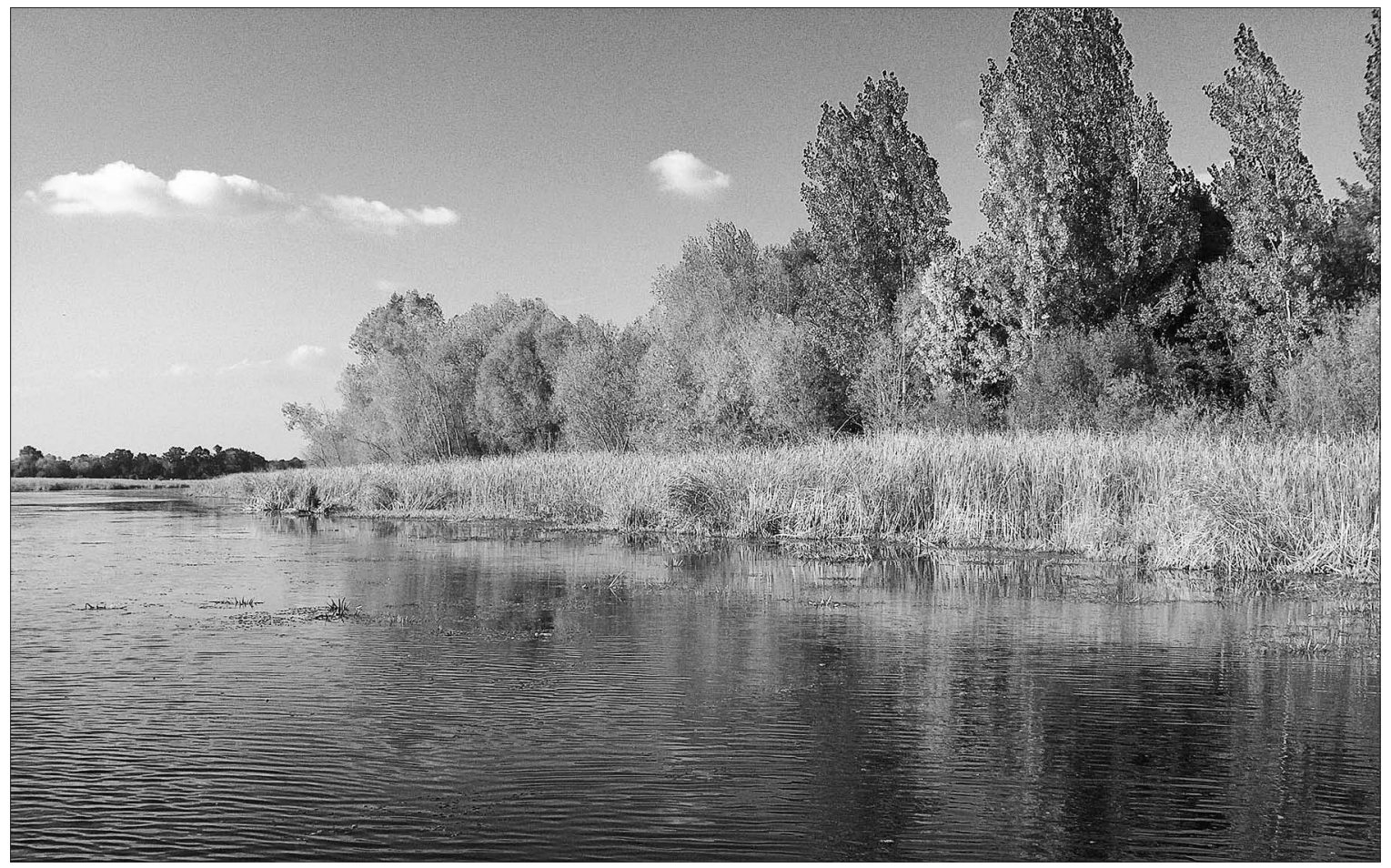

Figure 1. Special Nature Reserve Zasavica, in the vicinity of the Valjevac site (Photo: D. Dolinaj) 


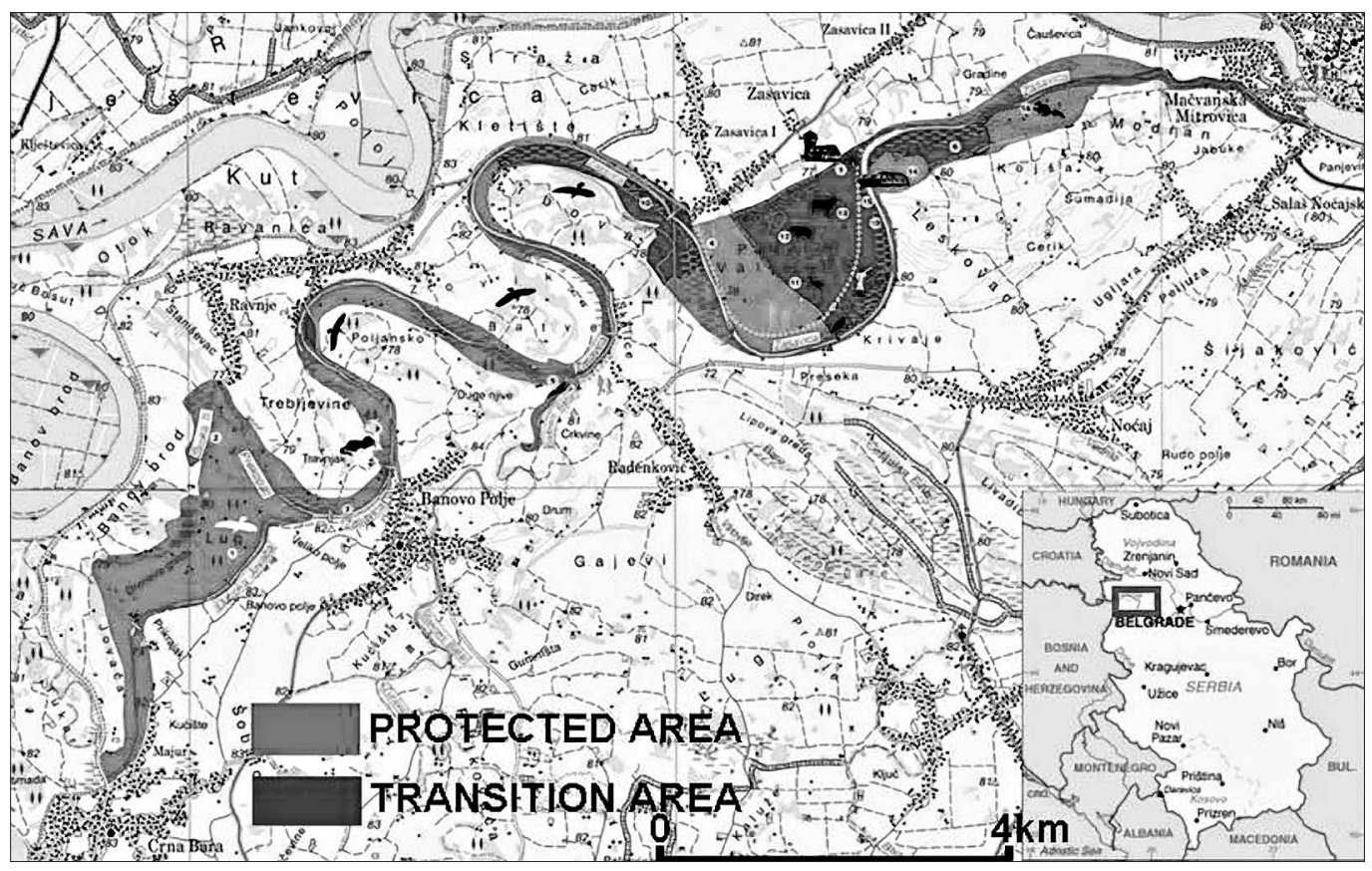

Map 1. The Location of the Special Nature Reserve of Zasavica with the protection features (Source: Goranski pokret Sremske Mitrovice; technical editing D. Dolinaj)

Noćajski and Mačvanska Mitrovica, if we are looking from its source to the river mouth into the Sava. Along the entire stream of Zasavica there is an asphalt road which connects all the mentioned communities of the north Mačva, so that the access to the region of Zasavica is practically available from all the neighbouring settlements through the asphalt road as well as the other side roads. In 1997 the government put this area under protection as the Special Nature Reserve Zasavica (Grčić, 2004).

Special Nature Reserve Zasavica, consists of the waterland of the Jovače and Prekopac canals, which were channeled and the natural stream of Batar, as well as Zasavica with its channelled and natural stream (Lazić et al, 2008). In the area of the farmland of the villages of Ravnje, Zasavica and Salaš Noćajski, the protected area stretches to the banks comprising forests and fields, the stretches of land of Bostanište, the reeds area and forests of Vrbovac, the grazeland of Valjevac with the reeds area along Zasavica, and the reeds area along the banks, fields and forests of Sadžak.

Zasavica starts in the village of Banovo Polje, where the waters of Jovače and the canal Prekopac (80.6 m alt.) flowing into the Sava near Mačvanska Mitrovica across the channel Bogaz (77.5 $\mathrm{m}$ alt.). The difference between the highest and the lowest point in the Zasavica catchment area is $8 \mathrm{~m}$, and the riverbed incline along the entire length of $33.1 \mathrm{~km}$ is only $3.1 \mathrm{~m}$, because the meanders on Zasavica are very common, and there are 6 of them in total. The total area of the Zasavica catchment area is $109 \mathrm{sq} \mathrm{km}$ and consists of the river Zasavica with Batar and its tributary Žurava. In the past, Mačva was covered with forests and marshes. From the middle of the 19th century, the forests started disappearing because they were cleared to provide arable land, and both bogs and reeds areas were disappearing together with the forests of Mačva. The forestland was cleared in the period 1860 to 1880 , which led to the present state in the $20^{\text {th }}$ century. 
The territory of the Special Nature Reserve Zasavica was given the 2nd level of protection with the area of 670.9989 ha. Special Nature Reserve is also surrounded by the protection area of 1150 ha. Administratively, the protection area belongs to two municipalities: Sremska Mitrovica and Bogatić. The distribution area by municipalities it belongs is as follows: the municipality of Sremska Mitrovica with 187 cadastre lots comprises a much larger part of the protected area -616.703 ha (91.9\%), whereas the municipality of Bogatic with 33 cadastre lots comprises the protected area of 54.2386 ha (8.1\%) (Institute of Nature Protection of Serbia, 1996). According to the land use structure, the grazing areas are dominant (43.61\%). The wetland comprises $23.88 \%$, out of which $20.98 \%$ belongs to Zasavica. The forestland $(16,74 \%)$ and reeds area $(11,5 \%)$ are also present to a large extent (Institute of Nature Protection of Serbia, 1996). The arable land (fields) are present to a much smaller extent (3.92\%), whereas the areas of special use (meadows, roads, orchards, gardens) make only a small part of the total protection area.

\section{Methodological approach to the investigated area}

Contemporary research of the protected area is often based on the possibilities to link the research methods of different sciences, leading to a multidisciplinary character, which is inevitable today (Loucks, 2006). The field research provided data about spatial and biogeographical characteristics of the research area, which is a standard method in the contemporary spatial research of ecotourist and geographic character (Marković, 1961; Mikuska, Dušanić, 1983; Ristanović, Bubalo, 1998; Grčić, 2004; Dolinaj, 2006; Chhetri at all, 2004; Beunen at all, 2008; Pašić at all, 2009). The territory covered in the research is situated in the north of Mačva in the close vicinity of Sremska Mitrovica. This is a mainly agricultural area, where the Special Nature Reserve of Zasavica is situated. The limited protected areas often represent the only preserved natural entities, which offer a basis for the development of ecotourism with their unique characteristics (Chhetri at all, 2004; Dolinaj, 2006; Beunen at all, 2008). The additional analysis was conducted based on the cartographic materials, as well as satellite images in order to obtain a complete biogeographical image of the area. The satellite images have proven that there is a correlation of the protected area and the settlement entities in the surroundings (satellite image 1 and 2). The method of using cartographic elements on the satellite base was used by the authors to show possible solutions as results of the problem approach which is a basis of this research (appendix 1). The mapping method of the satellite base and spatial positioning of the suggested solutions, contributes to the clarity and more adequate presentation of the results, and the application of the research results is emphasized. Through further prospective research of the area, the emphasis would be on the universal application of the offered solutions, which makes the results more significant in the wider social context.

\section{The state and the development of the ecotourism as well as the opportunities for its spatial and functional connection to the rural tourism}

Lately, there has emerged a need for protection not only of the forms, landscapes and species which by definition represent landmarks (caves, natural landmarks, specific geomorphologic forms, endangered and rare flora and fauna, etc.) but also the areas which have become rare or disappearing because of the negative influence of men. This is the case with with the 
flood areas in the north Mačva, which is becoming more endangered due to melioration and the spreading of arable fields. One part of these areas belongs to the location known as Zasavica. In order to preserve it and stop its further disappearance, it was put under the state protection as a Special Nature Reserve Zasavica. The Reserve protects the other areas of lowland and flood land which used to stretch across hundreds of square kilometres of the territory of Srem and northern Mačva. Today these areas are disappearing, so this is one of the reasons to put this rivulet in the north of Mačva under the protection. Ecotourist movements on the territory of the Reserve are based on the preserved ecosystems of bog, marsh and swampy type, whose most attractive amenities are numerous rare and endangered species. Important rare species of flora are: white water lily (Nymphaca alba), yellow water lily (Numphar luteum), water soldier (Stratiotes aloides), greater spearwort (Ranunculus lingua), and sweet flag (Acorus calamus). Some of these plant species inhabiting this Reserve are included in The Red Book of Flora in Serbia: sweet flag (Acorus calamus), water violet (Hottonia palustris) and greater spearwort (Ranunculus lingua) (Institute of Nature Protection of Serbia, 1996). On the list of natural rarities there are some endemorelict species: swamp nettle (Urtica krioviensis) and triangular club-rush (Schenoplectus triqueter) and macrophyte species, and two insectivore representatives: Common Bladderwort (Urticularia vulgaris and Urticularia neglecta) (Institute of Nature Protection of Serbia, 1996; Stanković, 2008). The Reserve offers the protection to numerous endangered species of ichtiofauna: Mudminnow (Umbra krameri), Cruscian Carp (Carassius carassius), Tench (Tinca tinca); ornithofauna: Common Buzzard (Buteo butes), Hawk (Accipiter genus), Common Kestrel (Falco tinnunculus), and among mammals the most important representatives are: Otter (Lutra lutra) and European Beaver (Castor fiber),

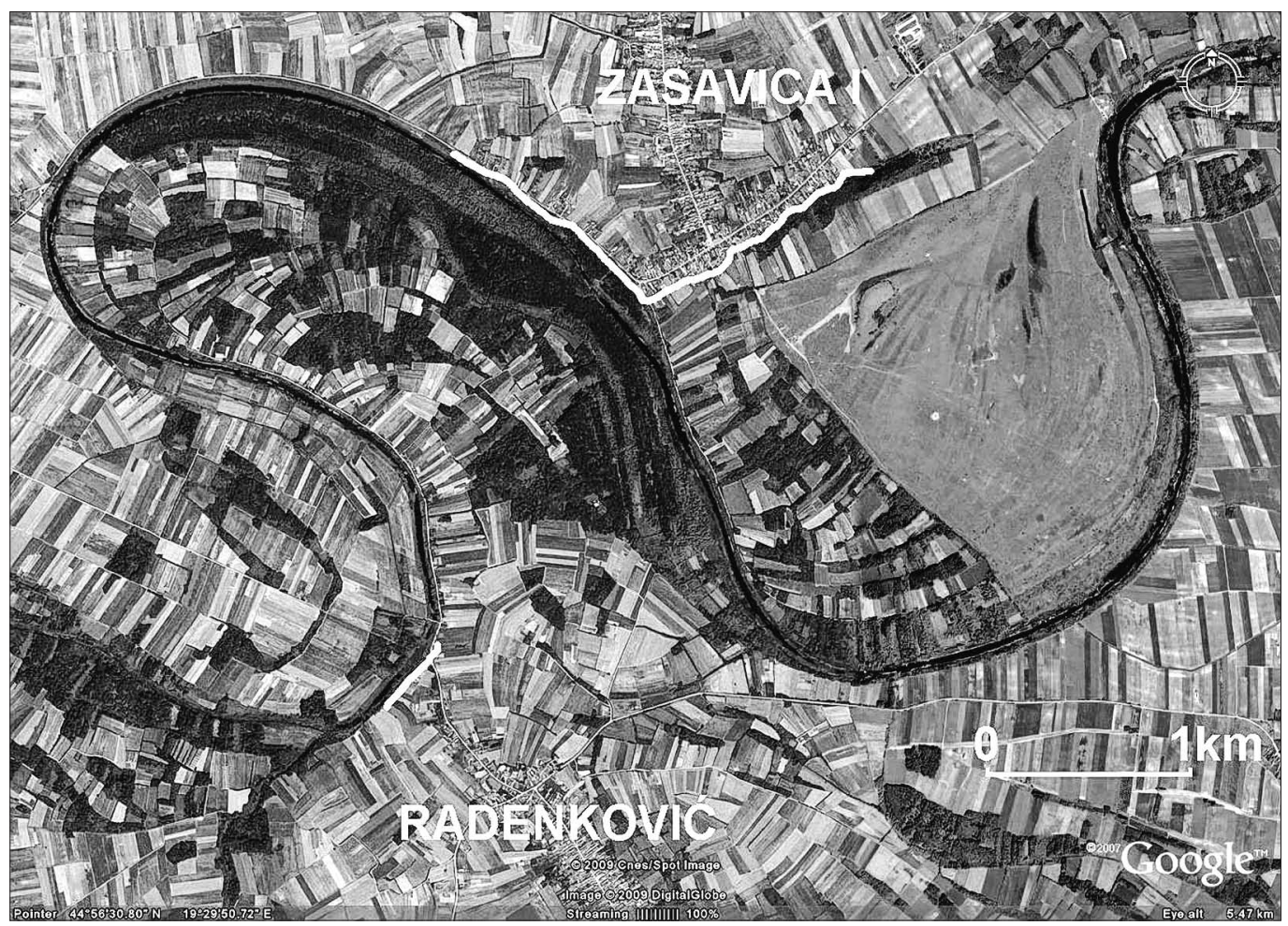

Satellite image 1. The contact line of the Special Nature Reserve Zasavica and village settlements in the villages of Zasavica I and Radenković (Source: Google Earth; technical editing D. Dolinaj) 


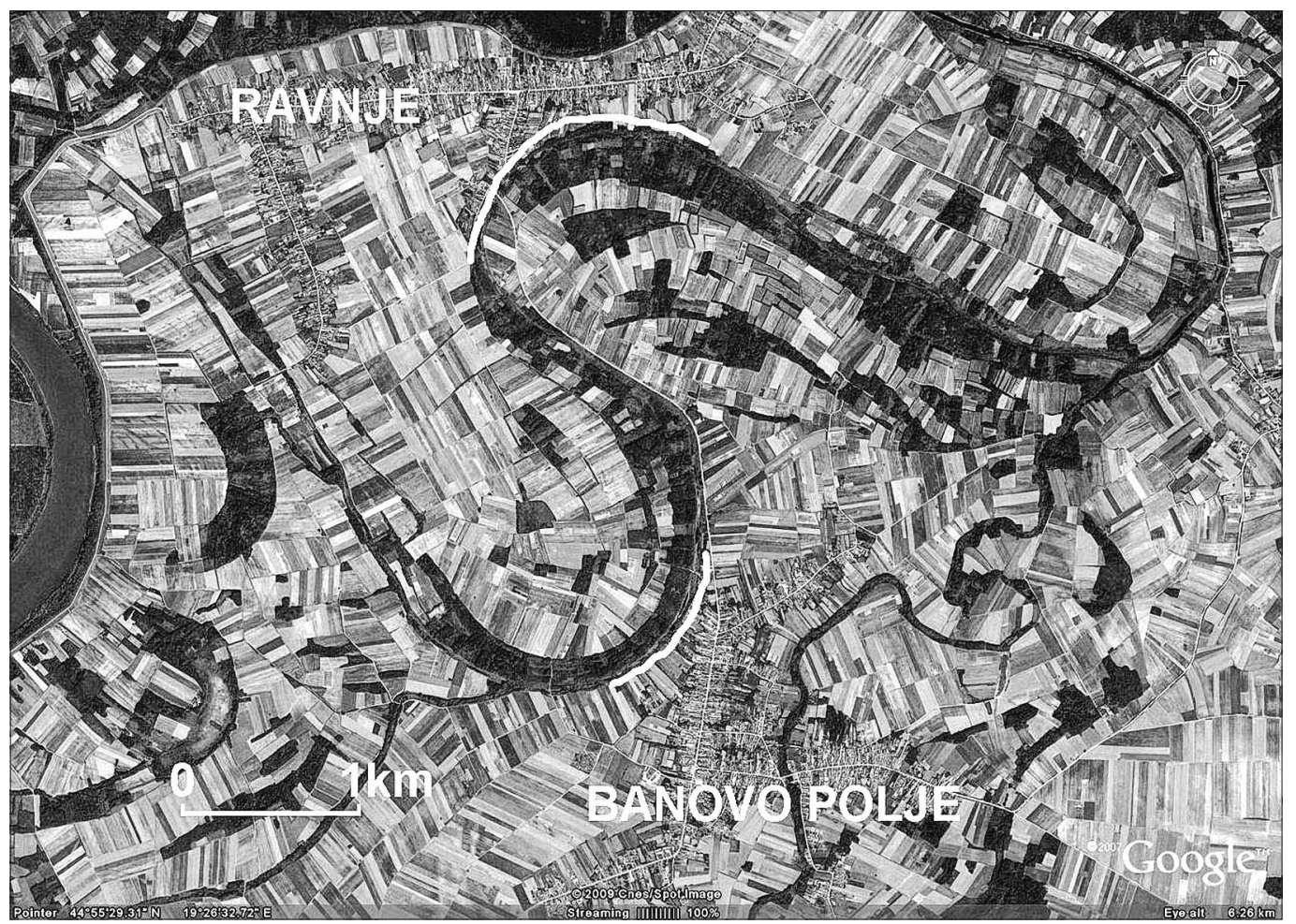

Satellite image 2. The contact line of the Special Nature Reserve Zasavica and village settlements in the villages of Ravnje and Banovo Polje (Source: Google Earth; technical editing D. Dolinaj)

which was reintroduced in 2004 (Stanković, 2008). All these rare and endangered species, as well as the marsh and swampy terrain, are a basis of the ecotourist offer of the north Mačva. The Nature Reserve Zasavica has been established on the tourist market with the ecotourist offer which basically aims at representing all of the preserved assets not only as an important biogenetic base for the preservation of individual endangered species, but also to represent all the attractiveness of these, unfortunately, rare ecosystems. The protection area of the region is situated among the numerous settlements of the north Mačva. The location of a reserve can contribute to particular problems related to the functioning of the reserve. Since 1997, when the region of Zasavica was put under protection, numerous problems were noticed related to the protection of the rivulet Zasavica and its bank area. In the total of four locations, along the Special Nature Reserve Zasavica, there is a spatial contact between the protected area and the residential settlements, i.e. residential buildings within the surrounding villages.

On the territory of Zasavica I, the close vicinity of the protected area to the private residential buildings with land plots in the length of $3 \mathrm{~km}$, near Ravanj $2.5 \mathrm{~km}$, Radenkovići $0.5 \mathrm{~km}$ and Banovo Polje $1.5 \mathrm{~km}$. Such spatial relationships can lead to problems in the protection of the reserve, and at the same time to preventing some agricultural activities of the nearby villages. As far as the Reserve is concerned, the problems are related to the level of protection in particular sectors where there is the contact with the settlements, and the reserve is endangered mainly because of the water and soil pollution. The wider area surrounding the reserve hydrologically gravitates to the lowest part, the flow of Zasavica, so at the same time a large quantity of wastewater (from the cattle buildings, septic systems, etc.) from the surrounding settlements is flowing into this rivulet. The fact that the settlements of the north Mačva still do not 
have a modern sewage system makes the situation even harder. The situation is getting worse in the periods of agricultural activities on arable areas, when the water and soil get additionally polluted due to unprofessional use of chemical additives. On the other hand, the local people see the Reserve as a source of problems related to the areas where arable land is close to the protected area. They often blame the animals from the Reserve for the crop destruction, and often express fear of some animals inhabiting the protected area. The existing problems can be solved with the cooperation of the local community with the managerial board of the Special Nature Reserve of Zasavica. There are some initiatives for starting the development of rural tourism on the territory of north Mačva and thus promoting the rural area of this part of Serbia with its ethnic characteristics. The Reserve Zasavica has its interest in the development of this type of tourism. With the arrival of a large number of tourists to the territory of Mačva, rural and ecotourism would become complementary, which would inevitably cause better cooperation of the local community and the management board of the Zasavica Reserve. If the local community depended on tourists, this would bring change in opinions and attitudes towards the Reserve, which would be evaluated more favourably due to the increased number of tourists, and consequently bringing higher revenues from rural tourism. The contact areas of the village settlements and protected areas can represent the region for merging these two types of tourist offer. The involvement of the local community in the tourist offer would start the process of restoring the trust between the community and the Reserve. This would solve the existing problems in the relationship between local communities and the reserve, and local population would find interest in solving the problem of wastewater, at the same time solving

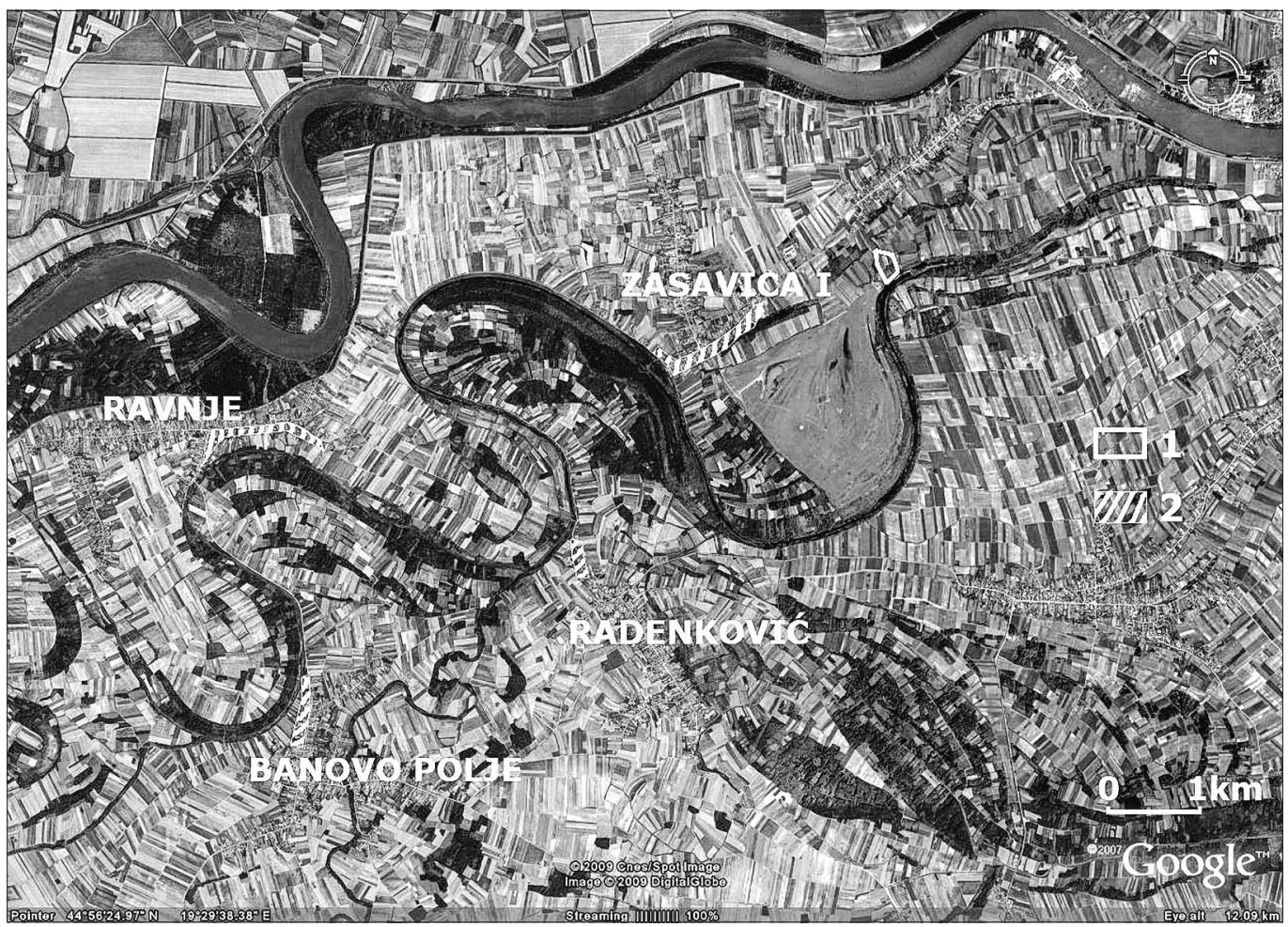

Appendix 1. Special Nature Reserve Zasavica - the analysis of the possible cooperation with the local community, 1-area of existing touristic objects, 2-area of potencial construction of touristic objects (Technical editing D. Dolinaj) 


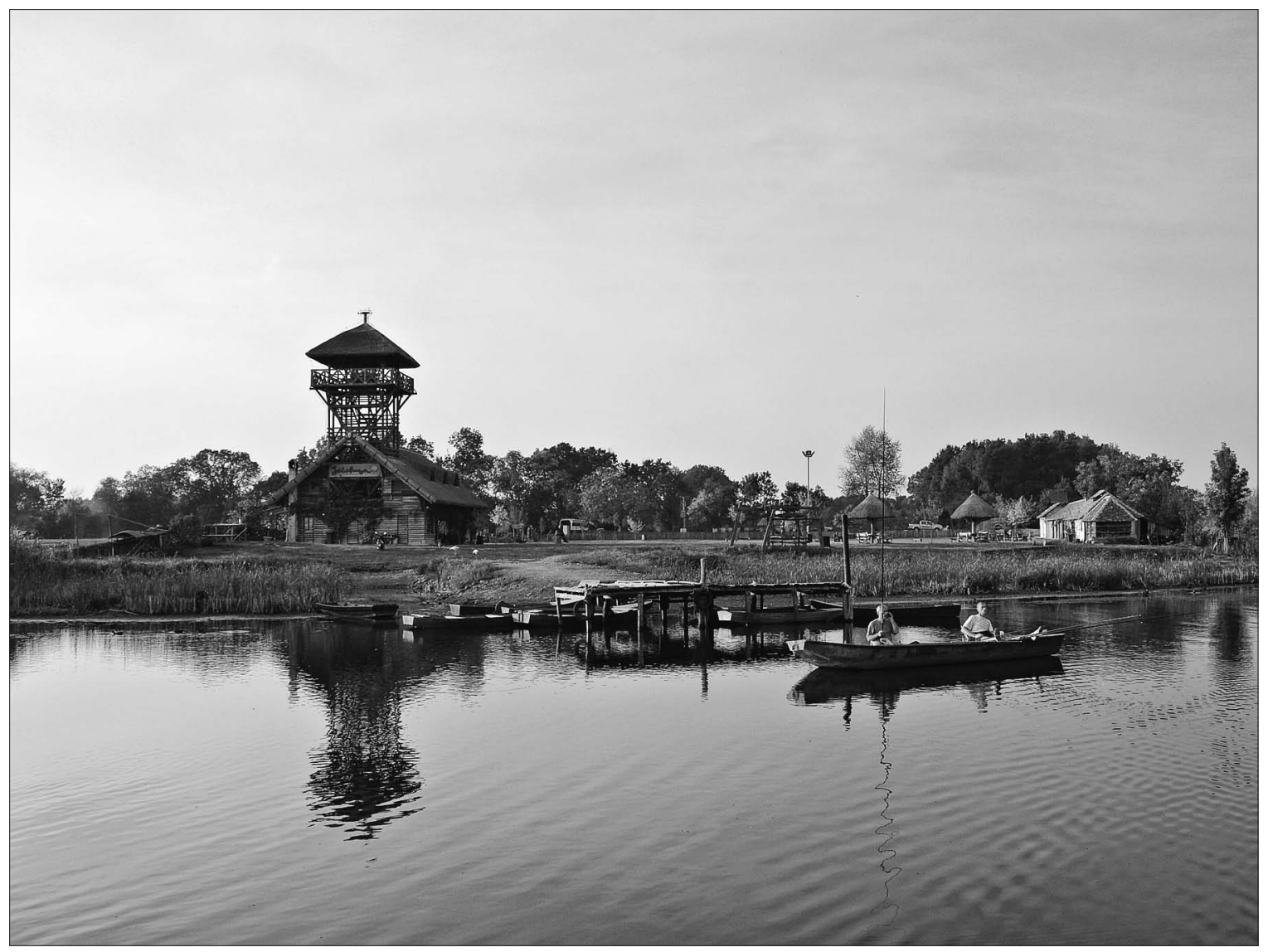

Figure 2. Special Nature Reserve Zasavica, the lookout point (Photo: D. Dolinaj)

the problem of water and soil pollution in the Reserve. The tensions related to crop destruction would be decreased, and the fear of wild animals would be decreased by educating the population. Starting ecotourism in the villages of the northern Mačva would help solving another problem in the ecotourist offer of the Special Nature Reserve Zasavica.

Presently, the reserve does not have accommodation offer, so accommodating tourists in village households would solve the problem of longer tourist stays, which would additionally conect the offer of village and ecotourism, and local community would have one further reason to support the Special Nature Reserve of Zasavica.

\section{Conclusion}

The protection of the endangered areas, ecosystems and wildlife is extremely important for the preservation of biodiversity, as well as special habitats on the territory of Vojvodina and the entire Serbia Proper. The participation of the local communities in the protection is of the utmost importance and represents a necessity which contributes to the better preservation and presentation of the protected area. Involving local community in this process is most easily done through the development of different forms of tourist movements which can be connected to this protected natural asset. Thus the reserve or another natural asset is not only a 
limited area in their surroundings with the strict protection regime, but it becomes economically connected to the local community whose revenues become partly dependent on the protected area. This partnership represents a solid base for the cooperation between the management of the reserve and the local communities and their inhabitants.

\section{References}

Beunen, R., Regnerus, D., H., Jaarsma, F., C. (2008). Gateways as a means of visitor management in national parks and protected areas. Tourism Management, 29, 138-145.

Chhetri, P., Arrowsmith, C., Jackson, M. (2004). Determining hiking experiences in naturebased tourist destinations. Tourism Management, 25, 31-43.

Dolinaj, D. (2006). Sportsko-ribolovni turizam, novi turistički trend. Gea, Prirodno matematički fakultet, Departman za geografiju, godina VI, br. 27, april, Novi Sad.

Grčić, LJ. (2004). Specijalni rezervat prirode Zasavica na severu Mačve. Zemlja i ljudi, Srpsko geografsko društvo, sv. 54, Beograd.

Lazic, L., Pavić, D., Stojanović, V., Tomić, P., Romelić, J., Pivac, T., Košić, K., Besermenji, S., Kicošev, S., Đarmati, Z., Puzović, S., Đureković-Tešić, O., Stojanović, T., Marić, B., Vig, L., Panjković, B., Habijan - Mikeš, V., Sabadoš, K., Delić, J., Kovačević, B., Stojšić, V., Korać, J. (2008). Zaštićena prirodna dobra i ekoturizam Vojvodine. Departman za geografiju, turizam i hotelijerstvo, prirodno-matematički fakultet, Novi Sad.

Loucks, P., D. (2006). Modeling and managing the interactions between hydrology, ecology and economics. Journal of Hydrology, 328, 408-416.

Markoska, D. (1972). Geografski prikaz Mačve, PMF, Beograd.

Markoska, D. (1986). Hidrološke karakteristike Mačve. Godišnjak međuopštinskog arhiva, Šabac.

Marković, J. (1961). Makroplavine u Jugoslaviji. Zbornik 6. kongresa geografa, Ljubljana.

Matvejev, S., (1950). Zaštita ptica, Zaštita prirode, Beograd.

Mikuska, J., Dušanić. D. (1983). Uticaj turizma na zaštićene objekte prirode. Zaštita, uređivanje i unapređivanje Obedske bare, Pokrajinski zavod za zaštitu prirode, Novi Sad.

Pašić, M., Dolinaj, D., Stojanović, V. (2009). The importance of preservation of autochthonous biotope of Pannonian plane in the area of Special nature reserve "Pašnjaci velike droplje" for education and ecptourism development. Turizam 12, Novi Sad.

Ristanović, B., Bubalo, M. (1998). Mogućnosti implikacija turističkih kretanja na eko-sistem prirodnog rezervata Zasavica. Turizam, Prirodno-matematički fakultet, Institut za geografiju, turizam i hotelijerstvo, br. 2, Novi Sad.

Seleši, Đ. (1991). Proces eutrofizacije u Vojvođanskim akumulacijama i jezerima. Vode Vojvodine, Godišnjak vodoprivrede Vojvodine, Novi Sad.

Stanković, M. (2008). Evropski dabar (castor fiber) vrednost, istorijske promene i rezultati praćenja reintrodukcije na Zasavici. Ekoist'o8, Sokobanja.

Stanković, M. (2008). Međunarodna i nacionalna vrednost biodiverziteta specijalnog rezervata prirode Zasavica. Ekoist'o8, Sokobanja.

Stojanović, V. (2006). Održivi razvoj turizma i životne sredine. Departman za geografiju, turizam i hotelijerstvo, prirodno-matematički fakultet, Novi Sad.

Tomić, P., Romelić, J., Kicošev, S., Besermenji, S., Stojanović, V., Pavić, D., Pivac, T., Košić, K., Puzović, S., Habijan - Mikeš, V., Panjković, B., Sabadoš, K. Štetić, J., Kovačević, B., Stojšić, 
V., Korać, J. (2004). Zaštićena prirodna dobra i ekoturizam Vojvodine. Departman za geografiju, turizam i hotelijerstvo, prirodno-matematički fakultet, Novi Sad.

Vasić, V. (1984). Biogeografske karakteristike ptica vodenih staništa Balkanskog poluostrva. Doktorska disertacija, Prirodno-matematički fakultet, Beograd.

Zakon o zaštiti životne sredine. Službeni glasnik Republike Srbije, Broj 66/91, Beograd.

Zaštita prirode (1991). Prilog za prostorni plan Srbije (Plan zaštite prirodnih dobara). Republički zavod za zaštitu prirode, Beograd.

Zavod za zaštitu prirode Srbije (1996). Specijalni rezervat prirode Zasavica. Stručna dokumentaciona osnova, Beograd.

Zavod za zaštitu prirode Srbije (1996). Specijalni rezervat prirode zasavica. Predlog za kategorizaciju, Beograd. 